\title{
Impact of Frontline Demonstrations on Production and Productivity of Pulses in Arid Regions of Nagaur District of Rajasthan
}

\author{
B.L. Jat ${ }^{1}$, A.S. Jat ${ }^{1}$, I. Singh ${ }^{2}$
}

10.18805/ag.D-5399

\begin{abstract}
Background: Pulses are well known richest source of vegetable protein and is known as poor man's food because of its essential component in diet. The frontline demonstrations of pulses were carried out on 311.8 ha area with 694 demonstrations in different clusters of Nagaur district of Rajasthan.

Methods: Front line demonstrations on chickpea, mung bean and moth bean crop were conducted by Krishi Vigyan Kendra, Nagaur-I, Agriculture University, Jodhpur during rabi and Kharif season of 2011-12 to 2019-20.

Result: In demonstrations up to $29.43 \%, 30.29 \%$ and $35.22 \%$ yield increase of chickpea, mungbean and moth bean crop was observed over the farmer's practices in the year 2011-12, 2017 and 2016. The yield gap between improved technology and conventional farmer's practices was ranging from 1.98 to $4.54 \mathrm{q} / \mathrm{ha}, 0.61$ to $2.55 \mathrm{q} / \mathrm{ha}$ and 0.6 to $1.68 \mathrm{q} / \mathrm{ha}$, respectively. Whereas, the highest net returns of $₹ 71,881 \mathrm{ha}^{-1}$, ₹ $45,884 \mathrm{ha}^{-1}$ and $₹ 14,315 \mathrm{ha}^{-1}$ was observed in the year 2019-20, 2014 and 2016 , respectively with the highest incremental cost benefit ratio of 1:3.71, 1:3.95 and 1:1.97 under demonstrations practices.

Key words: Arid regions, Chickpea, Front line demonstrations, Moth bean, Mung bean, Productivity.
\end{abstract}

\section{INTRODUCTION}

In terms of agricultural importance, pulses are next to cereal crops and are also known as excellent option for agriculture diversification and intensification in sustainable farming. India is the largest producer and consumer of pulses and contribute in about 35 per cent share in global area and production. The pulse production in India has been fluctuated widely leading to steady decline in the per capita availability over last 20 years (Gregory et al., 2003). Over the last six years, the on-going National Food Security Mission (NFSM) has been converged with multi-pronged strategies to enhance the production and productivity of pulses in the country (Anonymous, 2018) which results in enhanced per hectare productivity. The year 2017-18 witnessed a record pulse production of 25.23 million tonnes (Anonymous, 2018), a grand success story and revolution in pulses selfsufficiency.

The country is now trying to meet the target of 35 million tonnes by 2030 with the challenging reasons like unavailability of quality seed, lack of technical guidance, ignorance of Integrated Pest Management techniques and non-adoption of integrated nutrient management (Kumar et al., 2014; 2016). Besides this, major abiotic stress i.e. low organic content in soil, low moisture content in the soil, types of soils, seasonal drought due to low rainfall are also responsible for low productivity of the pulses crops (Dubey et al., 2017). Among biotic stress, legume pod borer, Helicoverpa armigera (Hübner) is responsible for 50 to 60 per cent grain yield losses (Balikai et al., 2001) and losses exceeded ₹ 12,000 million per year (Anonymous, 1996). Therefore, it is a great deal for extension scientists, policy
${ }^{1}$ Krishi Vigyan Kendra, Nagaur-I, Agriculture University, Mandore342 304, Jodhpur, Rajasthan, India.

${ }^{2}$ Directorate of Extension Education, Agriculture University, Mandore-342 304, Jodhpur, Rajasthan, India.

Corresponding Author: B.L. Jat, Krishi Vigyan Kendra, Nagaur-I, Agriculture University, Mandore-342 304, Jodhpur, Rajasthan, India. Email: bljat.hau@gmail.com

How to cite this article: Jat, B.L., Jat, A.S. and Singh, I. (2022). Impact of Frontline Demonstrations on Production and Productivity of Pulses in Arid Regions of Nagaur District of Rajasthan. Agricultural Science Digest. DOI: 10.18805/ag.D-5399.

Submitted: 02-06-2021 Accepted: 02-12-2021 Online: 22-02-2022

makers and farming community to meet out the pulses availability demand over the country population in terms of household nutritional security.

To overcome the pulses hunger, government tried to improve pulses production and productivity in the country with Indian Council of Agricultural Research by taking major big step for the same by conducting Cluster Frontline Demonstrations nationwide through Krishi Vigyan Kendras with the mandate of out scaling of farm innovations through FLDs to highlight the specific benefits/ worth of technologies on farmer's fields. Besides this, various programmes like Technology Mission in 1986, National Pulse Development Project in 1990-91, Integrated Scheme of Oilseeds, Pulses, Oil palm and Maize in 2004, National Food Security Mission in 2007-08 and Accelerated Pulses Production Programme (A3P) has been started by the government (Kumar et al., 2021) but gap between demand and supply is still bigger 
and this demand gap is tried to overcome through import of pulses.

The utmost objective of the frontline demonstrations is to large scale technological demonstrate latest technologies of crop production and management practices under diverse climatic conditions as well as farming situations to fill the per cent yield gap. Therefore, the effect of frontline demonstrations on production and productivity of pulses has been studied in rainfed areas of Nagaur district of Rajasthan.

\section{MATERIALS AND METHODS}

Front line demonstrations on chickpea, mung bean and moth bean were conducted by Krishi Vigyan Kendra, Nagaur-I, Agriculture University, Jodhpur during rabi and Kharifseason from $2011-12$ to $2019-20$. Total 311.8 ha area was covered with 694 demonstrations in different clusters in Nagaur district. Nagaur district is situated between 260.25" to 270.40" North latitude and 730.18" to 750.15" East longitude. The average rainfall of the zone is $360 \mathrm{~mm}$. In general, soils of the area under study were sandy to sandy loam in texture with average $\mathrm{pH} 7.8$, organic carbon 0.32 , low in nitrogen and medium in phosphorus and potash.

Cluster selections, farmer selection, problem diagnosis, layout of demonstration were carried out as suggested by Choudhary (1999). Assessment of gap in adoption of recommended technology was done before laying out FLD's through personal discussion with selected farmers (Table 1). Trainings were organized about detailed technological intervention with improved package and practice for successful cultivation of pulses. In the demonstrated FLDs the recommended package of practices were followed for crop cultivation and compared with the farmer's practices (Table 1). In case of farmers practice plots, existing practices being used by farmers were followed.

Scientists visited regularly demonstration fields and farmer's fields. The feedback information from the farmers was also recorded for further improvement in research and extension programmes. The extension activities i.e. trainings, interaction with farmers and field days were organized at the cluster frontline demonstration sites. The basic information were recorded from the farmer's field and analyzed to comparative performance of demonstrated plot and local check.

Data on yield parameters from demonstrated plots and farmers practices was collected by random crop cutting method and the cost of cultivation, gross return, net return and benefit cost ratio etc. were analyzed by simple statistical analysis. Observations on grain yield (qt/ha), straw yield (qt/ ha) and harvest index (\%), yield increase over farmers practices $(\%)$, technology gap ( $q / h a)$, technology index (\%) and extension gap ( $\mathrm{q} / \mathrm{ha}$ ) etc. were also worked out by methods suggested by Samui et al. (2000):

Extension gap $(\mathrm{q} / \mathrm{ha})=$

Demonstrations yield $(q / h a)$ - Yield under farmer's practices $(q / h a)$

Technology gap $(q / h a)=$

Potential yield $(q / h a)$ - Demonstrations yield ( $q / h a)$

$$
\text { Technology index }(\%)=\frac{\text { Technology gap }(q / h a)}{\text { Potential yield }(q / h a)} \times 100
$$

\section{RESULTS AND DISCUSSION}

The performance of pulse crops owing to the adoption of improved technologies was assessed over a period of nine years from 2011-12 to 2019-20 and is presented in Fig 1,2,3 and Table 2. The economics of cost of cultivation, gross return, net return, additional cost, additional return and benefit: cost ratio were analyzed and presented in Table 3 .

\section{Economic yield (q/ha)}

Data of 694 demonstration results from the Table 2 represents the average seed yield of the pulses crops. Under demonstration technology, the average seed yield of chickpea, mung bean and moth bean crops was $18.02,8.36$ and $5.37 \mathrm{q} / \mathrm{ha}$, respectively. Whereas, the same was 14.51 , 6.97 and $4.17 \mathrm{q} / \mathrm{ha}$, respectively under farmer's practices. The average per cent yield increase of respective crops over farmer's practices was $24.18 \%, 19.59 \%$ and $28.36 \%$, respectively. From the results, it is witnessed that the performance of improved varieties with proper practices found better than the conventional farmer's practices. Possible reasons for variations in the seed yield range could be low quality seed as well as unpredictable rainfall.

Similarly, Kumar et al. (2019) also reported 0.83 to 14 $\mathrm{q} /$ ha grain yield of different pulse crops under demonstrations as compared to 0.72 to $8.40 \mathrm{q} / \mathrm{ha}$ in farmer's practices. The per cent yield increase of chickpea crop was 28.57 to $30.28 \%$ in the similar dry areas (Kumar et al., 2021).

\section{Extension gap ( $q / h a)$}

The extension yield gap ranged from 0.6 to $4.54 \mathrm{q} /$ ha was observed between demonstrations technology and farmers practices in the respective crops (Fig 1, 2, 3). The maximum extension yield gap of $4.54 \mathrm{q} / \mathrm{ha}$ was observed in chickpea variety GNG-1581, whereas, the lowest $(0.61 \mathrm{q} / \mathrm{ha})$ was in mung bean variety Satya. Extension yield gaps can be changed through creating awareness among farming community about improved technology.

Avoiding the adoption of improved crop production technology by the farmers for better production results in extension yield gaps (Kumari et al., 2007). According to Parihar et al. (2018), the average extension yield gap in lentil crop was $1.83 \mathrm{q} / \mathrm{ha}$ under demonstrations which resulted in higher grain yield as compared to farmer's practices.

\section{Technology gap (q/ha)}

The results of frontline demonstrations yield and potential yield of pulses crops was compared to estimate the yield gaps, technology gap and technology index (Fig 1, 2, 3). The technology gap of pulses crops ranged from 0.67 to $8.57 \mathrm{q} / \mathrm{ha}$. It results that higher the value of technology gap more is the feasibility of the improved technology at the farmer's field. The variation in technology gap is common 


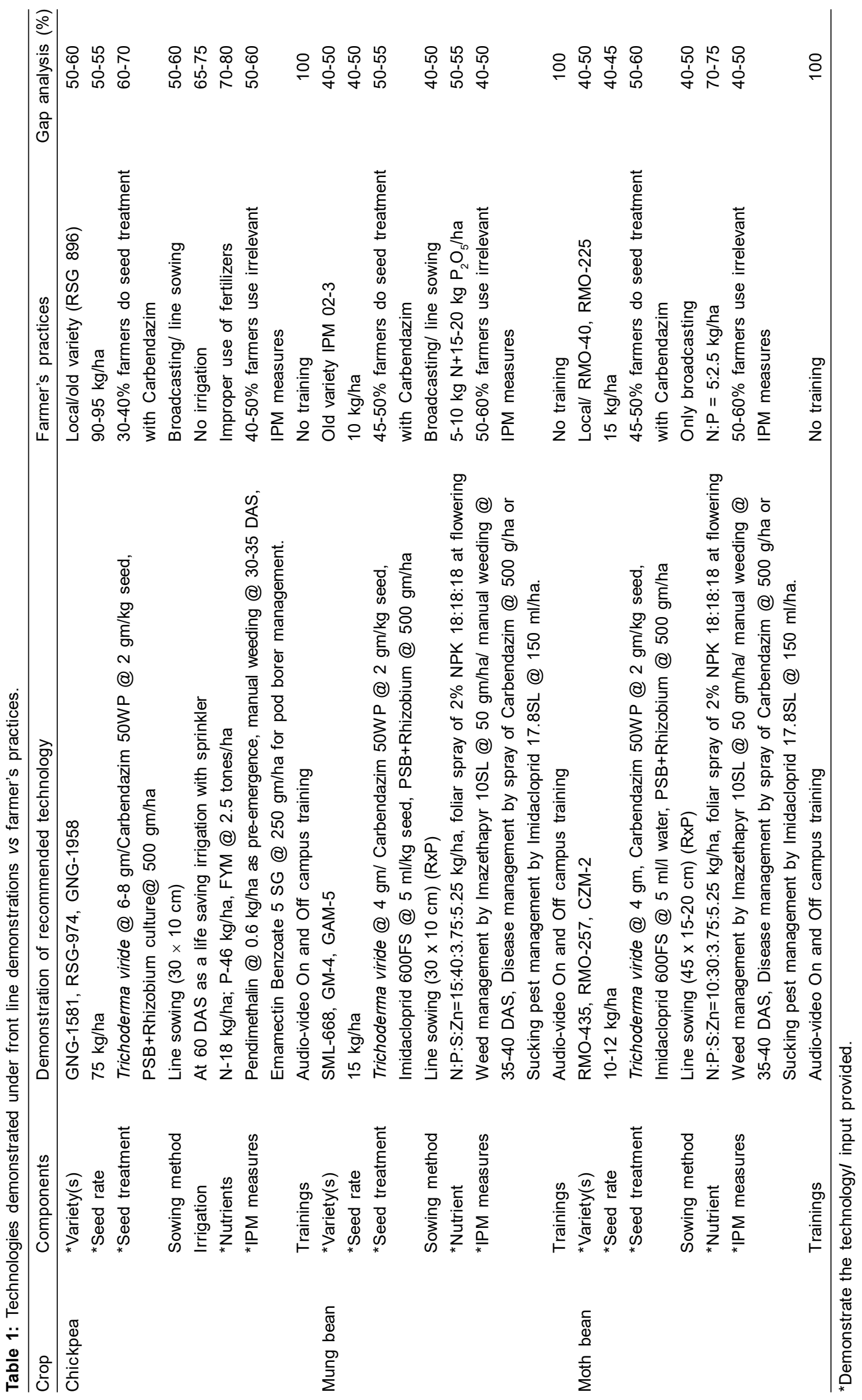


Impact of Frontline Demonstrations on Production and Productivity of Pulses in Arid Regions of Nagaur District of Rajasthan

and it appears even the LFDs are conducted under the strict supervision of scientist. The reasons may be lack of irrigation facility, low rainfall distribution, variation in soil fertility, local crop management practices etc. problems to get the yield potential of cultivars under demonstrations (Sagar and Chandra, 2004).
The results are in accordance to the findings of Parihar et al. (2018) and Kumar et al. (2019), according to them the technology gap in chickpea, mung bean and lentil crop was 9.5 to $13.0,6.62$ to $12.40,5.25$ to 10.50 and 3.61 to 4.42 q/ ha, respectively.

Table 2: Grain yield and per cent yield increase of pulse crops under FLDs.

\begin{tabular}{|c|c|c|c|c|c|c|c|}
\hline Year/ season & $\begin{array}{l}\text { Area of } \\
\text { demo. }\end{array}$ & $\begin{array}{l}\text { No. of } \\
\text { demo. }\end{array}$ & Variety (s) & $\begin{array}{l}\text { Potential yield } \\
\qquad(q / h a)\end{array}$ & $\begin{array}{l}\text { Demo. yield } \\
\text { (q/ha) }\end{array}$ & $\begin{array}{l}\text { FP yield } \\
\text { (q/ha) }\end{array}$ & $\begin{array}{c}\% \text { yield increase } \\
\text { over FP }\end{array}$ \\
\hline \multicolumn{8}{|c|}{ Chickpea (Rabi) } \\
\hline 2011-12 & 10 & 13 & RSG-888 & 25.0 & 17.35 & 13.49 & 28.61 \\
\hline $2011-12$ & 10 & 12 & RSG-963 & 22.0 & 17.28 & 13.35 & 29.43 \\
\hline 2014-15 & 12.5 & 25 & GNG-1581 & 24.0 & 21.38 & 17.79 & 20.17 \\
\hline 2015-16 & 16 & 47 & GNG-1581 & 24.0 & 16.50 & 13.30 & 24.06 \\
\hline $2016-17$ & 20 & 40 & GNG-1581 & 24.0 & 17.89 & 15.00 & 19.27 \\
\hline 2017-18 & 50 & 125 & RSG-974 & 23.0 & 14.24 & 12.26 & 16.15 \\
\hline $2018-19$ & 40 & 70 & GNG-1958 & 26.8 & 19.31 & 15.24 & 26.71 \\
\hline $2019-20$ & 20 & 50 & GNG-1581 & 24.0 & 20.19 & 15.65 & 29.01 \\
\hline Total & 178.5 & 382 & Average & 24.1 & 18.02 & 14.51 & 24.18 \\
\hline \multicolumn{8}{|c|}{ Mung bean (Kharif) } \\
\hline 2011 & 12 & 30 & RMG-62 & 10.0 & 9.33 & 7.27 & 28.33 \\
\hline 2013 & 10 & 20 & SML-668 & 14.0 & 11.25 & 8.7 & 29.31 \\
\hline 2014 & 10 & 20 & SML-668 & 14.0 & 11.16 & 9.27 & 20.39 \\
\hline 2015 & 5 & 10 & GM-4 & 14.0 & 7.50 & 6.19 & 21.16 \\
\hline 2016 & 10 & 25 & SML-668 & 14.0 & 10.32 & 9.33 & 10.61 \\
\hline 2017 & 10 & 20 & GM-4 & 14.0 & 6.14 & 5.41 & 13.49 \\
\hline 2017 & 7.6 & 19 & Satya & 14.0 & 6.00 & 5.39 & 11.32 \\
\hline 2018 & 30 & 75 & GAM-5 & 15.0 & 6.43 & 5.57 & 15.44 \\
\hline 2019 & 10 & 25 & GAM-5 & 15.0 & 7.12 & 5.64 & 26.24 \\
\hline Total & 104.6 & 244 & Average & 13.78 & 8.36 & 6.97 & 19.59 \\
\hline \multicolumn{8}{|c|}{ Moth bean (Kharif) } \\
\hline 2013 & 5 & 10 & RMO-435 & 7.0 & 5.93 & 4.36 & 36.00 \\
\hline 2014 & 5 & 10 & RMO-435 & 7.0 & 5.05 & 4.18 & 20.81 \\
\hline 2016 & 22 & 73 & RMO-257 & 8.0 & 6.45 & 4.77 & 35.22 \\
\hline 2017 & 11.2 & 28 & CZM-2 & 7.0 & 4.37 & 3.63 & 20.39 \\
\hline 2018 & 30 & 70 & RMO-435 & 7.0 & 5.25 & 4.08 & 28.68 \\
\hline 2019 & 20 & 50 & RMO-435 & 7.0 & 5.15 & 3.99 & 29.07 \\
\hline Total & 93.2 & 241 & Average & 7.17 & 5.37 & 4.17 & 28.36 \\
\hline
\end{tabular}

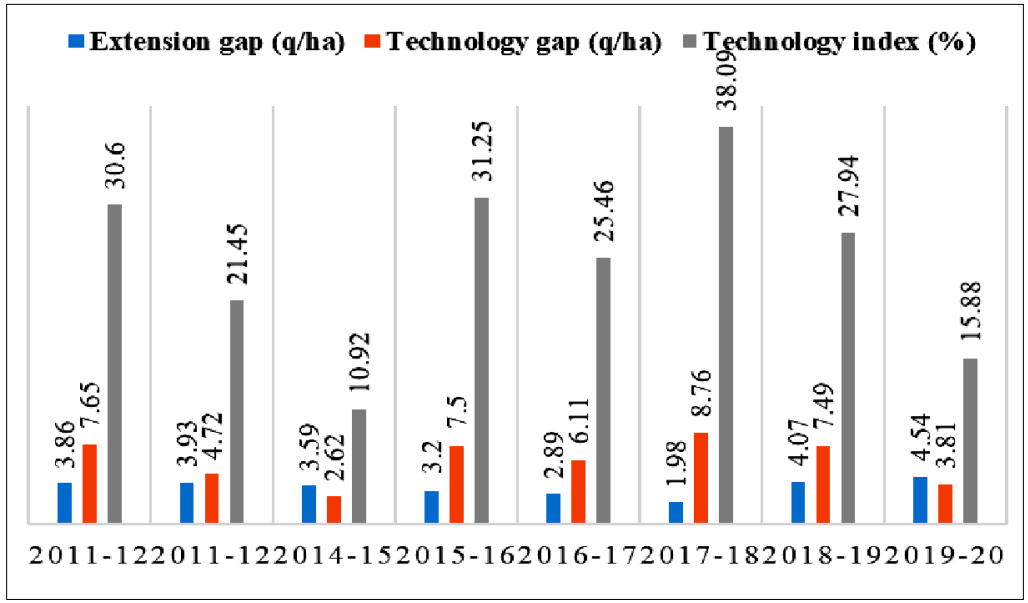

Fig 1: Extension gap, technology gap and technology index of chickpea crop. 
Impact of Frontline Demonstrations on Production and Productivity of Pulses in Arid Regions of Nagaur District of Rajasthan

\section{Technology index (\%)}

Similarly, the per cent technology index of chickpea, mung bean and moth bean ranged from 10.92 to $38.09 \%, 6.70$ to $57.14 \%$ and 15.29 to $37.57 \%$, respectively (Fig $1,2,3$ ). Per cent technology index represents technology gap and is the result of poor transfer of improved technology among farmers. Higher technology index for two varieties of mung bean crop during 2017 may be due to poor extension services or non-transferring of proven technology to the farmers.

The hypothesis proposed by Ram et al. (2014) and Dayanand et al. (2014) are in conformity with the present findings. According to them, the technology index of chickpea and urdbean crop was $25.20 \%$ and $50.33 \%$.

Table 3: Economic analysis of different pulse crops under front line demonstrations.

\begin{tabular}{|c|c|c|c|c|c|c|c|c|c|}
\hline \multirow{2}{*}{ Year/ season } & \multirow{2}{*}{ Variety } & \multicolumn{2}{|c|}{ Cost of cultivation ( $₹ / h a)$} & \multicolumn{2}{|c|}{ Gross return (₹/ha) } & \multicolumn{2}{|c|}{ Net return (₹/ha) } & \multicolumn{2}{|c|}{ Benefit cost ratio } \\
\hline & & Demo & FP & Demo & FP & Demo & FP & Demo & FP \\
\hline \multicolumn{10}{|c|}{ Chickpea (Rabi) } \\
\hline 2011-12 & RSG-888 & 11,108 & 8,872 & 32,880 & 25,551 & 21,772 & 16,679 & $1: 2.96$ & $1: 2.88$ \\
\hline $2011-12$ & RSG-963 & 11,002 & 8,823 & 32,677 & 25,145 & 21,675 & 16,322 & $1: 2.97$ & $1: 2.85$ \\
\hline $2014-15$ & GNG-1581 & 23,740 & 22,100 & 36,124 & 27,712 & 12,384 & 5,612 & $1: 1.52$ & $1: 1.25$ \\
\hline $2015-16$ & GNG-1581 & 24,500 & 22,250 & 57,750 & 46,550 & 33,250 & 24,300 & $1: 2.36$ & $1: 2.09$ \\
\hline $2016-17$ & GNG-1581 & 24,800 & 23,600 & 71,560 & 60,000 & 46,760 & 36,400 & $1: 2.89$ & $1: 2.54$ \\
\hline $2017-18$ & RSG-974 & 25,500 & 24,600 & 62,656 & 53,944 & 37,156 & 29,344 & $1: 2.50$ & $1: 2.20$ \\
\hline 2018-19 & GNG-1958 & 27,853 & 26,000 & 89,212 & 70,409 & 58,829 & 41,964 & $1: 3.20$ & $1: 2.71$ \\
\hline $2019-20$ & GNG-1581 & 26,545 & 25,495 & 98,426 & 76,294 & 71,881 & 50,799 & $1: 3.71$ & $1: 2.99$ \\
\hline \multicolumn{10}{|c|}{ Mung bean (Kharif) } \\
\hline 2011 & RMG-62 & 9,196 & 7,412 & 22,991 & 16,307 & 13,795 & 8,895 & $1: 2.50$ & $1: 2.20$ \\
\hline 2013 & SML-668 & 14,550 & 13,700 & 43,400 & 28,800 & 28,850 & 15,100 & $1: 2.98$ & $1: 2.10$ \\
\hline 2014 & SML-668 & 15,560 & 14,650 & 61,444 & 49,313 & 45,884 & 34,663 & $1: 3.95$ & $1: 3.37$ \\
\hline 2015 & GM-4 & 15,700 & 14,800 & 48,050 & 37,815 & 32,350 & 23,015 & $1: 3.06$ & $1: 2.56$ \\
\hline 2016 & SML-668 & 18,462 & 17,615 & 53,922 & 48,749 & 35,460 & 31,134 & $1: 2.92$ & $1: 2.77$ \\
\hline 2017 & GM-4 & 13,250 & 12,900 & 34,231 & 30,161 & 20,981 & 17,261 & $1: 2.58$ & $1: 2.34$ \\
\hline 2017 & Satya & 13,250 & 12,900 & 33,450 & 30,049 & 20,200 & 17,149 & $1: 2.52$ & $1: 2.33$ \\
\hline 2018 & GAM-5 & 18,575 & 16,725 & 44,849 & 38,851 & 26,274 & 22,126 & $1: 2.41$ & $1: 2.32$ \\
\hline 2019 & GAM-5 & 19,675 & 17,750 & 50,196 & 39,762 & 30,521 & 22,012 & $1: 2.55$ & $1: 2.24$ \\
\hline \multicolumn{10}{|c|}{ Moth bean (Kharif) } \\
\hline 2013 & RMO-435 & 12,750 & 12,200 & 22,831 & 16,786 & 10,081 & 4,586 & $1: 1.79$ & $1: 1.38$ \\
\hline 2014 & RMO-435 & 15,200 & 14,220 & 20,200 & 16,720 & 5,000 & 2,500 & $1: 1.33$ & $1: 1.18$ \\
\hline 2016 & RMO-257 & 14,710 & 12,900 & 29,025 & 21,465 & 14,315 & 8,565 & $1: 1.97$ & $1: 1.66$ \\
\hline 2017 & CZM-2 & 10,900 & 10,000 & 22,069 & 18,332 & 11,169 & 8,332 & $1: 2.02$ & $1: 1.83$ \\
\hline 2018 & RMO-435 & 14,250 & 12,850 & 27,300 & 21,216 & 13,050 & 8,366 & $1: 1.92$ & $1: 1.65$ \\
\hline 2019 & RMO-435 & 15,775 & 13,650 & 28,325 & 21,945 & 12,550 & 8,295 & $1: 1.80$ & $1: 1.61$ \\
\hline
\end{tabular}

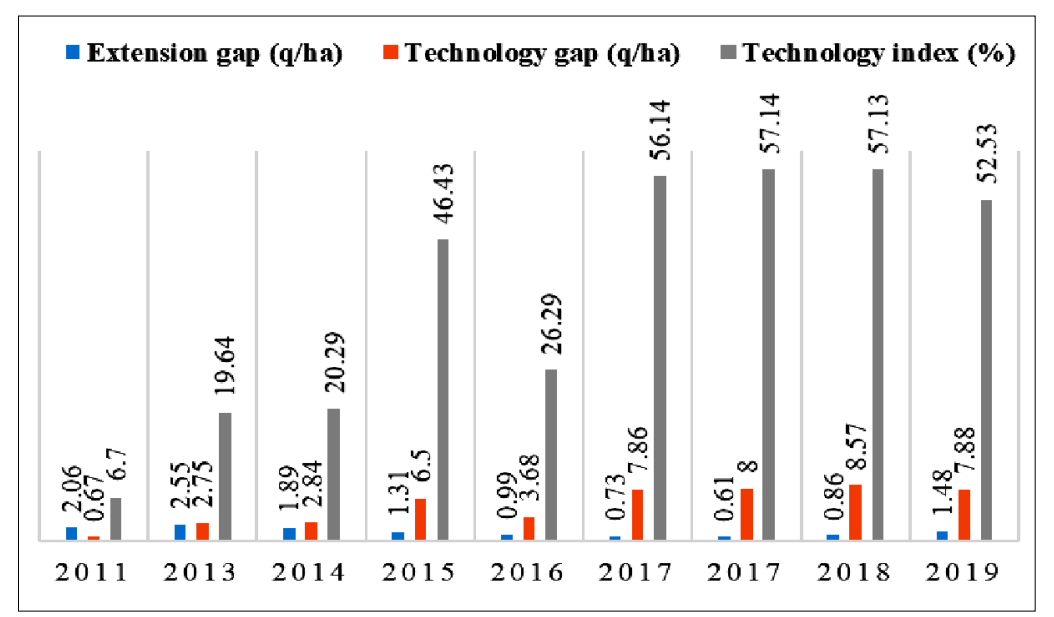

Fig 2: Extension gap, technology gap and technology index of mung bean crop. 


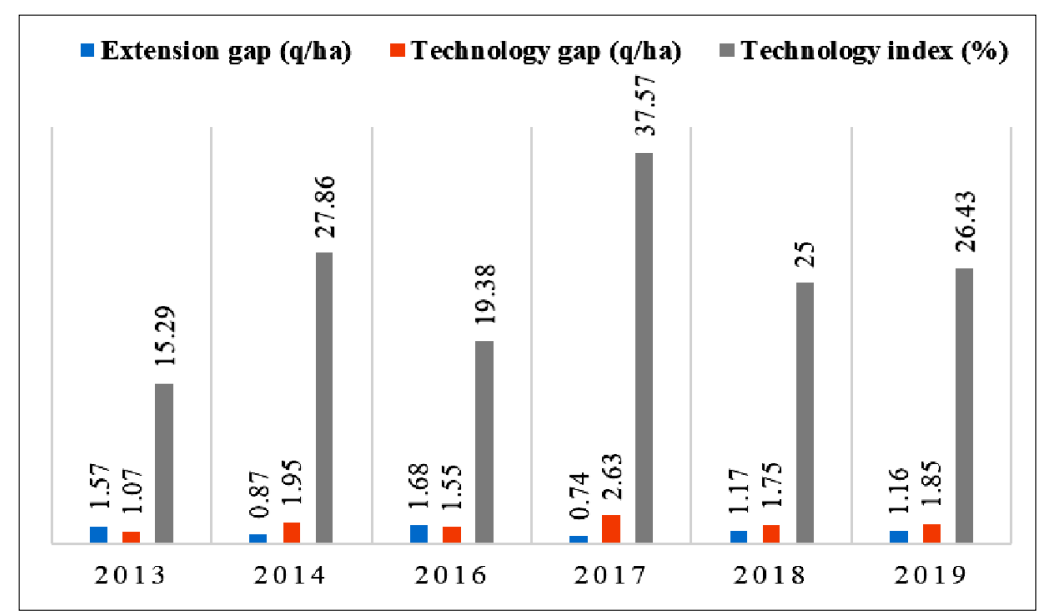

Fig 3: Extension gap, technology gap and technology index of moth bean crop.

\section{Monetary return analysis of frontline demonstrations}

The highest gross return (₹98,426 ha-1) and net return (₹ $71,881 \mathrm{ha}^{-1}$ ) under demonstrations was in chickpea variety GNG-1581 over the farmers practices (Table 3). Similarly, in mung bean (var. SML-668) and moth bean (var. RMO257 ), the same was ₹ 61,444 and ₹ 45,884 ha $^{-1}$ and ₹ 29,025 and $₹ 14,315 \mathrm{ha}^{-1}$, respectively. The benefit cost ratio was also highest $(1: 3.71)$ in chickpea variety GNG-1581 in demonstration plots as compared to farmer's practices (1:2.99). Similar trend was also observed in mung bean crop, in which the benefit cost ratio was $1: 3.95$ as compared to farmer's practices (1:3.37). However, in moth bean crop, the highest benefit cost ratio (1:2.02) was in variety CZM-2. Result data are the supportive evidences of improved interventions/technologies under demonstrations practices. Farmers can adopt the demonstrated technology to improve his monetary returns from their fields and leads to improve socio economic status and livelihood under the unpredictable drought conditions of the district.

Increasing in monetary returns and benefit cost ratio in pulses crops have been also reported by earlier workers (Ram et al., 2014; Dayanand et al., 2014; Lathwal, 2010). Similarly, demonstrations of improved technologies at farmer's field proven best to a great extent in enhancing the production and productivity of chickpea crop (Singh et al., 2017; Tomar, 2010).

\section{CONCLUSION}

The severe to moderate drought conditions have been noticed frequently in western regions of Rajasthan. Even though up to $35 \%$ yield increase of pulses crops over farmer's practices are witnessed of creating confidence and friendly relationships between farm scientists and village community. In Nagaur district of Rajasthan, the production and productivity of pulses was quite low earlier. Now, National Food Security Mission a government initiative tried to bridges a connection to enhance the same due to popularization of improved technologies at farmer's field.
But, there is still a wide gap between potential and demo yield which needs more extension service among farming community for better crop production, productivity and net monetary returns of pulses with more emphasis.

\section{ACKNOWLEDGEMENT}

Authors are thankful to ICAR, New Delhi for providing financial assistance for conducting frontline demonstrations on pulses crops and Agricultural Technology Application Research Institute (ATARI), Zone-II, Jodhpur for proper guidance.

Conflict of interest: None.

\section{REFERENCES}

Anonymous (1996). Annual Report. ICRISAT, Patancheru, Hyderabad, Telangana. pp: 24-25.

Anonymous (2018). Pulses Revolution-From Food to Nutritional Security. Ministry of Agriculture and Farmer Welfare (DAC and FW), Govt. India. pp.-1-115.

Balikai, R.A., Biradar, A.P., Yelshetty, S. and Teggelli, R.G. (2001). Relative efficacy of some insecticides against chickpea pod borer, Helicoverpa armigera. Karnataka Journal of Agricultural Science. 14: 346-348.

Choudhary, B.N. (1999). Krishi Vigyan Kendra-A guide for KVK managers, Division of Agriculture Extension, ICAR; 73-78.

Dayanand, Verma, R.K. and Mehta, S.M. (2014). Assessment of technology gap and productivity gain through frontline demonstration in chickpea. Legume Research. 37 : 430-433.

Dubey, S., Raghav, R.S. and Singh, P. (2017). Enhancement of productivity for chickpea (Cicer arietinum L.) through front line demonstration in farmer's field. Legume Research. 40: 335-337.

Gregory, K., Price, L.R. and Govindan, A. (2003). Electronic outlook report of economic research service, USDA. WRS-0301, May, 2003. pp 1-23.

Kumar, S., Khar, S., Sharma, M. and Singh, P. (2014). Stability analysis for seed yield attributing traits in chickpea (Cicer arietinum) under Mid Hills of JandK. Legume Research. 37: 552-555. 
Kumar, S., Mahajan, V., Sharma, P.K. and Parkash, S. (2019). Impact of front line demonstrations on the production and productivity of moong, Vigna radiata, mash, Vigna mungo, rajmash, Phaseolus vulgaris, lentil, Lens culinaris and chickpea, Cicer aeritinum under rainfed ecology in mid hills of $\mathrm{J}$ and K, India. Legume Research. 42: 127-133.

Kumar, S., Singh, P., Khar, S. and Sharma, M. (2016). Variability association studies of screening of genotypes against pea seed born mosaic virus (PSMV) in lentil (Lens culinaris) under NW Himalayas of Jammu Kashmir. Legume Research. 39: 26-30.

Kumar, U., Patel, G.A., Patel, H.P., Chudhari, R.P. and Darji, S.S. (2021). Impact of front line demonstration programme on the yield of chickpea (Cicer arietinum L.) in patan district of Gujarat, India. Legume Research. 44: 221-224.

Kumari, V., Kumar, A., Kumar, A. and Bhateria, S. (2007). Demonstration-an effective tool for increasing the productivity of rapseed-mustard in Kangra district of Himachal Pradesh. Himachal Journal of Agricultural Research. 33: 257-261.

Lathwal, O.P. (2010). Evaluation of frontline demonstrations on black gram in irrigated agro ecosystem. Annals of Agricultural Research. 31: 24-27.
Parihar, A.K., Dixit, G.P. and Gupta, S. (2018). Assessment of impact of frontline demonstrations in North Eastern-Hill region of India. Indian Journal of Hill Farming. Special Issue: 40-43.

Ram, B., Dhaka, B.L. and Punia, S.S. (2014). Evaluation of productivity and profitability of urdbean (cv. KU 96-3) under frontline demonstration in humid southeastern plain of Rajasthan. Journal of Food Legumes. 27: 246-248.

Sagar, R.L. and Chandra, G. (2004). Frontline demonstrations on sesame in West Bengal. Agricultural Extension Reviews. 16: 7-10.

Samui, S.K., Maitra, S., Roy, D.K., Mandal, A.K. and Saha, D. (2000). Evaluation of front line demonstration on groundnut, Arachis hypogeal. Journal of Indian Society of Coastal Agricultural Research. 18: 180-183.

Singh, J., Hundal, R.K. and Dhillon, B.S. (2017). Comparison for yield potential of chickpea in frontline demonstrations and farmer's practices in the amritsar district of Punjab. Current Agriculture Research Journal. 5: 239-243.

Tomar, R.K.S. (2010). Maximization of productivity for chickpea through improved technologies in farmer's field. Indian Journal of Natural Products and Resources. 1: 515-517. 